\title{
PENGEMBANGAN MODEL BIMBINGAN KARIR SISWA KELAS 1 SMA KOTA MADYA MEDAN DI ERA REVOLUSI INDUSTRI 4.0
}

\author{
Edidon Hutasuhut, Mirza Irawan, Utami Nurhafsari Putri
}

Surel: edidon.hutasuhut1@gmail.com

\begin{abstract}
This study aims to obtain teaching materials or career guidance materials that will be used in school. After conducting the research, it was found that 32 career guidance materials had been provided by BK teachers in SMA Negeri Medan. From this material, research was carried out on 30 alumni of Medan City Public High School. The results show that out of 32 materials, there are 6 materials that are unnecessary. Meanwhile, based on the opinion of 3 BK experts from the 6 materials, it can be used as a material entitled "Regional wealth and its development". Furthermore, to increase the shortage of wasted material in order to meet the number of hours that BK teachers in SMA in general, it is changed to: 1. Appropriate materials are sourced from text books. 2. Suitability between materials and conditions in the field. 3. The method used in conveying the material and media used. 4. Time required. 5. After 5 (five) materials are entered, the results of this study are used as a Career Guidance module.
\end{abstract}

Keywords: Career Guidance Material in Class 1 SMA, Text Books

\begin{abstract}
ABSTRAK
Penelitian ini bertujuan untuk mendapatkan bahan ajar atau materi bimbingan karir yang akan digunakan disekolah. Setelah dilakukan penelitian maka ditemukan 32 materi Bimbingan Karir yang selama ini diberikan oleh guru-guru BK di SMA Negeri Kota Medan. Dari materi tersebut dilakukan penelitian kepada 30 orang alumni dari SMA Negeri Kota Medan. Hasilnya menunjukkan bahwa dari 32 materi terdapat 6 materi yang tidak diperlukan. Sedangkan berdasarkan pendapat dari 3 orang pakar BK dari 6 materi tersebut dapat dijadikan 1 materi yang berjudul "Kekayaan daerah dan pengembangannya". Selanjutnya untuk menambah kekurangan materi yang terbuang agar memenuhi jumlah jam yang dimiliki guru BK di SMA pada umumnya, diganti menjadi: 1. Materi yang sesuai yang bersumber dari teks books. 2. Kesesuaian antar materi dengan keadaan dilapangan. 3. Metode yang digunakan dalam menyampaikan materi dan media yang digunakan. 4. Waktu yang diperlukan. 5. Setelah 5 (lima) materi dimasukkan maka hasil penelitian ini dijadikan modul Bimbingan Karir.
\end{abstract}

Kata Kunci : Materi Bimbingan Karir di Kelas 1 SMA, Teks Books

\section{PENDAHULUAN}

Siswa Sekolah Menengah Atas (SMA) termasuk individu-individu yang memasuki masa remaja yang berusia 15-18 tahun. Dengan rentang usia tersebut siswa termasuk dalam tahap perkembangan remaja. Salah satu tugas perkembangan remaja SMA adalah memiliki kesiapan untuk menghadapi dunia kerja ataupun karir. Havighurst (Yusuf, 2004: 83) menyatakan bahwa pada masa remaja terdapat beberapa tugas perkembangan yang harus diselesaikan, salah satu tugas 
perkembangan yang harus dicapai siswa SMA yaitu memilih dan mempersiapkan karir atau pekerjaan.

Menurut Super (dalam Umam Suherman, 2008: 119) remaja dikatakan bermasalah dalam karirnya manakala tidak mencapai kematangan karir sesuai dengan tahap dan tugas perkembangan karirnya, yang ditunjukkan dalam perilaku : 1) kurang mampu merencanakan karir dengan baik, 2) malas melakukan eksplorasi, 3) kurang memadainya pengetahuan tentang membuat keputusan karir, 4) kurang memiliki pengetahuan (informasi) tentang dunia kerja, 5) kurang memadainya pengetahuan tentang kelompok pekerjaan yang lebih disukai, 6) tidak mencapai realisme keputusan karir, dan 7) tidak memadainya orientasi karir sehingga akibatnya tidak mampu membuat perencanaan dan keputusan karir yang tepat.

Dewasa ini perubahan sosial secara fundamental sedang terjadi yang berakibat kepada cara hidup masyarakat harus mampu menyesuaikan diri dalam berbagai segi untuk memenuhi kebutuhan hidupnya. Perubahan tersebut dipicu oleh kegiatan indutsri yang menggabungkan teknologi otomatisasi dengan teknologi cyber di era revolusi industri 4.0. Otomatisasi dan pertukaran data dalam teknologi manufaktur, termasuk di dalamnya sistem cyber-physical, Internet of Thinngs (IoT), komputasi awan serta komputasi kognitif telah merasuk dalam berbagai kegiatan masyarakat.
Menghadapi perkembangan teknologi yang semakin pesat akan berdampak pula pada siswa yang ingin melanjutkan pendidikannya atau yang langsung memasuki dunia kerja. Hal ini disebabkan oleh pekerjaan yang biasanya dilakukan oleh manusia sekarang sudah digantikan oleh mesinmesin atau peralatan lain sebagai gantinya dengan alasan karena relatif lebih cepat dan lebih hemat biaya. Revolusi industri ini membawa peluang sekaligus tantangan terutama bagi siswa. Kondisi seperti ini semakin mendorong pentingnya melakukan bimbingan karir agar siswa dapat merencanakan karir yang tepat di era revolusi industri 4.0 dengan harapan siswa tidak salah dalam mengambil keputusan karir di masa depan. Dengan demikian, dalam membantu meningkatkan perencanaan karir siswa dapat diawali dengan memberikan berbagai informasi karir yang jelas agar siswa dapat memilah dan memilih jenis pekerjaan yang ada sehingga siswa dapat merencanakan karir sesuai dengan karakteristik dirinya.

Adanya persaingan ketat untuk memasuki dunia kerja maupun masuk ke Universitas unggulan membuat pengangguran semakin meningkat yang berasal dari lulusan Sekolah Menengah Atas (SMA). Sesuai informasi dari Badan Pusat Statistik Indonesia (BPS) per Februari 2019 yaitu jumlah angkatan kerja 136,18 juta orang dan tingkat pengangguran terbuka berdasarkan tingkat dari jenis pendidikannya maka presentase pengangguran tamatan Sekolah Menengah Kejuruan (SMK) sebesar 
$8,63 \%$, disusul pada Sekolah Menengah Atas (SMA) sebesar $6,78 \%$.

\section{Badan Pusat Statistik (BPS)} mencatat peningkatan angka pengangguran di Sumatera Utara pada 2019 jumlahnya naik sekitar 11.000 orang dari 403.000 orang menjadi 414.000 orang dibandingkan Februari 2018. Selanjutnya jumlah angkatan kerja pada Februari 2019 tercatat sebanyak 7,45 juta orang naik menjadi 224.000 orang dibandingkan pada Februari 2018. Sejalan dengan itu Tingkat Partisipasi Angkatan Kerja (TPAK) juga naik 1,21 point. Dalam setahun terakhir TPT turun 0,03 poin menjadi 5,56\% pada Februari 2019. Dilihat dari tingkat pendidikan, TPT jenjang universitas mendominasi yaitu sebesar 8,76\% (BPS, 2019).

Bimbingan karir merupakan salah satu aspek yang paling penting dalam menempuh karir dan perkembangan karir individu. Kecakapan dalam mengambil keputusan merupakan tujuan dalam merencanakan karir yang harus ditempuh oleh setiap individu.

Terkait dari keadaan diatas, terdapat beberapa permasalahan di sekolah. Berdasarkan wawancara pada Guru Bimbingan Konseling diperoleh informasi bahwa masih ada siswa yang belum mengetahui informasi tentang dirinya sendiri baik minat, bakat dan kemampuan yang dimilikinya. Masih banyak siswa yang belum bisa memutuskan arah karir mereka. Siswa juga kurang mengetahui informasi mengenai pendidikan lanjutan dan keahlian yang diperlukan dalam satu bidang pekerjaan, serta tidak mengetahui bentuk-bentuk karir yang akan berkembang dan diperlukan dimasa yang akan datang. Hal ini mengakibatkan siswa merasa kebingungan dalam melanjutkan ke arah mana jurusan yang akan dipilihnya atau bekerja dimana setelah lulus dari SMA.

Fenomena diatas menunjukkan bahwa informasi mengenai karir penting dimiliki oleh siswa melalui bimbingan karir agar mereka setelah lulus mampu memiliki kesiapan kerja, maka siswa SMA perlu mempersiapkan diri dalam hal perencanaan karir. Oleh karena itu, layanan bimbingan dan konseling perlu digiatkan kembali mengingat peluang dan tantangan yang akan dihadapi siswa nantinya dan supaya siswa juga dapat mempersiapkan dirinya dengan cara membuat perencanaan karir sejak jauh hari serta menentukan alternatif pilihan karir yang tepat agar mampu mengikuti perubahan yang terjadi di era revolusi industri 4.0.

Salah satu upaya yang dapat diberikan untuk menyelesaikan permasalahan karir siswa yaitu dengan memberikan bimbingan karir kepada siswa.

Dari beberapa uraian di atas terkait dengan judul penelitian ini yaitu Pengembangan Model Bimbingan Karir di SMA, maka penelitian ini akan menyusun bahan bimbingan karir dengan menggunakan teori-teori karir dan dipadukan dengan bahan yang sudah ada digunakan serta melakukan FGD dengan melibatkan para pakar Bimbingan karir selanjutnya akan 
dilakukan uji coba kepada alumni pengguna, sampai mendapatkan bahan yang relavan.

\section{METODE PENELITIAN}

Penelitian ini merupakan penelitian dasar dengan pendekatan penelitian pengembangan, yang luarannya berupa modul bimbingan karir di kelas I SMA yang digunakan oleh guru BK dalam membimbing karir siswa disekolah.

Populasi dalam penelitian ini adalah guru BK SMA di Kota Medan yang berjumlah 238 orang. Dari populasi ini peneliti mengambil sampel sebanyak 30 orang guru BK $(12,5 \%)$ dan 30 orang alumni sebagai pembanding.

Menurut Borg dan Gall (1989) ada sepuluh langkah pelaksanaan penelitian dan pengembangan yaitu:

Penelitian dan pengumpulan data

Pada langkah ini peneliti akan mengumpulkan data tentang bahanbahan bimbingan karir yang dilakukan dengan mewawancarai guru-guru yang ada di SMA tentang pelaksanaan bimbingan karir selama ini. Dalam pengumpulan data ini peneliti akan mendokumentasi kan jenis-jenis buku atau modul yang masing-masing mereka gunakan selama ini. Dari hasil keterangan yang diperoleh dari guruguru BK se-kota Medan akan terkumpul segala informasi tentang buku, paket, atau modul yang dapat dijadikan sebagai bahan pelaksanaan bimbingan karir. Setelah segala sesuatu hal tersebut terkumpul maka peneliti akan menyesuaikan nya dengan teori-teori tentang bimbingan karir yang bersumber dari buku lain kemudian akan mendiskusikan nya dengan tiga orang pakar.

\section{Perencanaan}

Berdasarkan penelitian dan pengumpulan data dari guru-guru SMA kota Medan dan ditambah dengan sumber buku-buku yang lebih update di era revolusi 4.0 ini, maka peneliti akan menyusun draft bahan ajar yang terdiri dari 27 judul materi yang dipersiapkan untuk diajarkan disetiap pertemuan kelas oleh guru BK dengan durasi waktu pengajaran 40 menit.

Pengembangan draf produk

Pada langkah ini peneliti akan menyusun instrumen untuk menilai kesesuaian materi BK yang telah disusun dengan keperluan informasi karir yang ada di masyarakat saat ini. Setelah instrumen ini diuji cobakan kelapangan, kemudian instrumen ini di diskusikan dengan 3 orang pakar yang menggeluti tentang bimbingan karir di sekolah. Hasil uji coba diperoleh bahwa materi bimbingan karir yang digunakan selama ini berjumlah 32 materi.

Uji coba lapangan awal

Instrumen yang telah direvisi selanjutnya diujikan kepada 30 orang alumni yang isinya menyangkut tentang kemanfaatan materi bimbingan karir yang diberikan dikelas selama ini dengan kenyataan yang ada dilapangan tentang pekerjaan baik menyangkut tentang tuntutan, 
suasana, minat dan bakat, gaji yang ada di masyarakat. Berdasarkan hasil uji coba diketahui bahwa materi bimbingan karir selama ini yang kurang bermanfaat adalah materi potensi hutan di lingkungan sekitar, potensi pertanian di lingkungan sekitar, potensi pertambangan di lingkungan sekitar, potensi peternakan di lingkungan sekitar, potensi laut di lingkungan sekitar, dan potensi transportasi di lingkungan sekitar. berdasarkan masukan dari 3 orang pakar dianalisis dan menjadi masukan kepada perbaikan materi yang akan disempurnakan.

Merevisi hasil uji coba

Berdasarkan hasil uji materi bimbingan karir dan hasil diskusi kepada 3 orang pakar maka materi bimbingan karir yang telah disempurnakan diujikan kepada 30 alumni.

Uji coba lapangan

Setelah bahan ajar direvisi dan menuju kesempurnaan maka bahan ajar ini diujikan kepada 30 orang guru SMA Negeri Medan dimana mereka disertai dengan form penilaian untuk memberikan masukan atau sanggahan terhadap materi-materi yang telah disempurnakan hasilnya.

Penyempurnaan produk hasil uji lapangan

Berdasarkan masukanmasukan yang ada dari guru sebagai pihak pengguna maka bahan ajar ini direvisi dengan melibatkan pakar dan disempurnakan.
Uji pelaksanaan lapangan

Pada langkah ini buku yang sudah menuju kesempurnaan dicetak sebanyak 30 examplar untuk digunakan oleh guru BK dikelas 1 agar dapat diterapkan untuk siswa/i yang ingin mencari pekerjaan atau melanjutkan pendidikan di perguruan tinggi setelah tamat SMA

Penyempurnaan produk akhir

Setelah 30 guru membaca bahan ajar bimbingan karir maka peneliti melakukan observasi wawancara sekaligus mengumpulkan masukanmasukan yang ada pada 30 orang guru.

Diseminasi dan implementasi

Pada langkah ini peniliti melaksanakan seminar yang dihadiri oleh 100 orang guru dan alumni. Sehingga bahan ajar bimbingan karir ini dapat diterbitkan dan memiliki ISBN.

\section{HASIL PENELITIAN DAN PEMBAHASAN}

Berdasarkan hasil pengumpulan data kepada 30 orang guru BK di SMA Kota Medan diperoleh bahwa juduljudul materi yang disampaikan oleh guru BK kepada siswanya selama ini, diantaranya yaitu:

a. Pemahaman Diri. Materi pokok pemahaman diri terdiri dari beberapa sub materi pokok, yaitu kemampuan berpikir, mengenal bakat, mengenal minat, mengenal hobi, mengenal sikap, pentingnya prestasi, kebutuhan hidup, gaya hidup, dan cita-cita. 
b. Pemahaman Nilai-Nilai. Materi pokok pemahaman nilai terdiri dari beberapa sub materi pokok, yaitu nilai-nilai kehidupan, saling mengenal nilai-nilai orang lain, pertentangan nilainilai dalam diri, pertentangan nilai-nilai pribadi dengan orang lain, nilai-nilai yang bertentangan dengan kelompok masyarakat, serta bertindak atas nilai-nilai pribadi.

c. Pemahaman lingkungan. Materi pokok pemahaman lingkungan terdiri dari beberapa sub materi pokok, yaitu informasi perguruan tinggi, potensi hutan di lingkungan sekitar, potensi pertanian di lingkungan sekitar, potensi pertambangan di lingkungan sekitar, potensi peternakan di lingkungan sekitar, potensi laut di lingkungan sekitar, potensi transportasi di lingkungan sekitar, serta informasi jabatan.

d. Hambatan dan cara mengatasinya. Materi pokok hambatan dan cara mengatasinya terdiri dari beberapa sub materi pokok, yaitu faktor pribadi, faktor lingkungan, manusia dan hambatan, serta cara mengatasi hambatan.

e. Merencanakan masa depan. Materi pokok merencanakan masa depan terdiri dari beberapa sub materi pokok, yaitu menyusun informasi diri, mengelola informasi diri, mempertimbangkan alternatif, keputusan dan rencana, serta merencanakan masa depan.

Pembahasan
Setelah materi terkumpul peneliti menganalisis pada 3 orang pakar BK, yaitu kepada Prof. Dr. Abdul Munir, M.Pd, Prof. Dr. Abdul Murat, M.Pd dan guru Dra. L. Banjarnahor. Dari hasil diskusi dengan 3 orang pakar BK, bahwa terdapat beberapa materi yang harus diperbaiki, diantaranya yaitu: materi potensi hutan di lingkungan sekitar, potensi pertanian di lingkungan sekitar, potensi pertambangan di lingkungan sekitar, potensi peternakan di lingkungan sekitar, potensi laut di lingkungan sekitar, dan potensi transportasi di lingkungan sekitar. Oleh sebab itu, maka materi-materi tersebut akan disatukan menjadi satu sub materi pokok yaitu kekayaan daerah dan pengembangannya.

Perencanaan

Pada tahap ini judul-judul materi dilengkapi dengan berbagai sumber, berdasarkan masukan dari pakar-pakar BK. Maka berdasarkan masukan tersebut ditentukan materi yang lengkap sebagai penyempurnaan modul yang akan dibagikan kepada 30 guru.

Pengembangan draf produk

Pada tahap ini peneliti menyusun instrumen yang berbentuk angket yang akan dibagikan kepada 30 orang alumni. Dalam menyusun instrumen, peneliti berdiskusi tentang kelayakan instrumen tersebut untuk 
diuji cobakan kelapangan kepada 3 pakar BK.

Uji coba lapangan awal

Pada langkah ini materi yang sudah disempurnakan akan dijabarkan dalam bentuk instrumen. Tujuan daripada diberikannya instrumen ini adalah untuk mengetahui sejauh mana materi sangat dibutuhkan oleh siswa sehingga instrumen ini hasilnya akan menjadi acuan dalam menentukan materi yang akan dipakai atau yang tidak dipakai.

Merevisi hasil uji coba

Berdasarkan hasil uji coba instrumen maka yang menjadi perbaikan terhadap materi adalah instrumen nomor $11,17,18,19,20$, 21, dan 22. Setelah materi-materi tersebut diperbaiki maka modul BK dapat disusun.

\section{Uji coba lapangan}

Bahan ajar yang telah direvisi diujikan kepada 30 orang guru BK SMA Negeri Medan. Berdasarkan penilaian yang diberikan oleh 30 guru BK tentang 27 materi, maka hasilnya dikatakan semua materi telah memenuhi syarat dan sangat bermanfaat untuk dijadikan bahan ajar BK di sekolah.

Penyempurnaan produk hasil uji lapangan

Untuk lebih menguatkan materi yang sudah dinilai oleh 30 orang guru BK meskipun materi dinilai mendekati kesempurnaan, peneliti masih meminta pendapat 3 orang pakar BK, hasilnya yaitu semua materi dapat dijadikan bahan ajar BK.

Uji pelaksanaan lapangan

Bahan ajar yang telah disempurnakan dicetak sebanyak 30 examplar untuk digunankan oleh guru BK di kelas 1 agar siswa memperoleh pemahaman tentang apa yang akan disiapkan selama menjadi siswa di SMA.

Penyempurnaan produk akhir

Setelah 30 guru membaca bahan ajar bimbingan karir yang diberikan kepadanya, maka peneliti meminta informasi dan melakukan observasi serta wawancara untuk mendapatkan atau memperoleh saran-saran dari guru agar materi bahan ajar lebih sempurna.

\section{Diseminasi dan implementasi}

Sebagai langkah terakhir materi yang telah dibaca oleh guru, diseminarkan kepada 100 orang guru dan alumni. Dari hasil pantauan selama mengikuti seminar, dapat disimpulkan bahwa bahan ajar bimbingan karir layak untuk dipublikasikan dan dapat dijadikan buku yang ber-ISBN.

\section{SIMPULAN}

Berdasarkan hasil laporan kemajuan penelitian ini, maka peneliti dapat menyimpulkan bahwa materi bimbingan karir yang digunakan selama ini sebagian harus berubah karena tidak diperlukan akibat dari kemajuan teknologi era revolusi industri 4.0. 
Oleh karena itu, layanan bimbingan dan konseling perlu digiatkan kembali mengingat peluang dan tantangan yang akan dihadapi siswa nantinya dan supaya siswa juga dapat mempersiapkan dirinya dengan cara membuat perencanaan karir sejak jauh hari serta menentukan alternatif pilihan karir yang tepat agar mampu mengikuti perubahan yang terjadi di era revolusi industri 4.0. Salah satu upaya yang dapat diberikan untuk menyelesaikan permasalahan karir siswa yaitu dengan memberikan layanan informasi karir kepada siswa.

\section{DAFTAR RUJUKAN}

Adiputri dan Dwikurnaningsih. 2014. Pengaruh Layanan Informasi Karier Terhadap Kemampuan Perencanaan Karier Siswa Kelas XI Sma Negeri 2 Cepu. UKSW

Anisa, Laelatul. 2015. Model Layanan Informasi Karir Dengan Teknik Field Trip Untuk Meningkatkan Perencanaan Karir Siswa Smk Di Kabupaten Demak. Universitas Muria Kudus

Arikunto, Suharsimi. 2006. Prosedur Penelitian. Jakarta: Rineka Cipta

Atmaja, Twi. 2014. Upaya Meningkatkan Perencanaan Karir Siswa Melalui Bimbingan Karir dengan penggunaan Media Modul. Psikopedagogia Badan Pusat Statistik. 2019. Februari 2019: Tingkat Pengangguran Terbuka (TPT) sebesar 5,01 persen. (Online) dalam https://www.bps.go.id/pressrele ase/2019/05/06/1564/februari2019--tingkat pengangguranterbuka--tpt--sebesar-5-01persen.html diakses pada tanggal 20 Mei 2019

Cepi, Risyana. 2018. Tantangan Pendidikan di Era Revolusi Industri 4.0 Kuliah Umum Universitas Negeri Malang (Online) dalam http://um.ac.id/content/page/2/2 018/11/tantangan-pendidikanera-revolusi-industri-4-0 diakses pada tanggal 11 Februari 2019

Dewi, $\quad$ Rosmala. 2016. Profesionalisasi Guru Bimbingan Konseling Melalui Penelitian Tindakan Bimbingan Konseling. Medan : Unimed

Dillard, Wulan Ayodya. 2013. Mau Kemana Setelah SMK. Jakarta: Esensi, Erlangga Group Harlock, Elizabeth B. 1980. Psikologi Perkembangan Suatu Pendekatan Sepanjang Rentang Kehidupan. Jakarta: Erlangga

Karnawati, D. 2017. Revolusi industri, $75 \%$ jenis pekerjaan akan hilang. (Online) dalam https://ekbis.sindonews.com/rea d/1183599/34/revolusi-industri75-jenis-pekerjaan-akan-hilang1488169341 diakses pada tanggal 11 Februari 2019

Kemenristek Dikti. 2018. Digitalisasi Ancam Ratusan Juta Pekerjaan. (Online) dalam https://ekbis.sindonews.com/rea d/1357343/34/digitalisasiancam-ratusan-juta-pekerjaan1543109531 diakses pada tanggal 28 Maret 2019 
Edidon Hutasuhut, Mirza Irawan, Utami Nurhafsari Putri : Pengembangan ...

Mulyadi. 2016. Bimbingan dan Konseling di Sekolah dan Madrasah. Jakarta: Prenadamedia Group

Nurihsan, Ahmad Juntika. 2006. Bimbingan dan Konseling Dalam Berbagai Latar Kehidupan. Bandung: Refika Aditama

Prayitno dan Erman Amti. 2013. Dasar-Dasar Bimbingan dan Konseling. Jakarta: Rineka Cipta Retnaningdyastuti, Sri Rejeki. 2018. Tantangan Dan Peluang Siswa Dan Guru Bk Di Era Disrupsi. (Online) dalam http://prosiding.upgris.ac.id diakses pada tanggal 20 Januari 2019

Rosyadi, Slamet. 2018. Revolusi Industri 4.0: Peluang dan Tantangan bagi Alumni UniversitasTerbuka (Online) dalam https:// www.researchgate.net diakses pada tanggal 11 Januari 2019

Schwab, K. 2017. The fourth industrial revolution. Crown Business Press.

Suherman, Uman. 2009. Konseling Karir Sepanjang Rentang Kehidupan. Bandung: Sekolah Pasca Sarjana UPI

Sumiati dan Sukardi. 1993. Panduan Perencanaan Karir. Surabaya: Usaha Nasional

Suryabrata,Sumadi. 2009. Metodologi Penelitian. Jakarta: Rajawali Pers

Triyono. 2018. Mereka-Reka Strategi Bimbingan Dan Konseling Dalam Era Disrupsi/Revolusi
Industri 4.0 Bagi Generasi Z. (Online) dikutip pada: http://prosiding.upgris.ac.id, diakses pada tanggal 20 Januari 2019

Walgito, Bimo. 2005. Bimbingan dan Konseling Studi \& Karir. Yogyakarta: Andi

Winkel W.S dan Sri Hastuti. 2006. Bimbingan dan Konseling di Institusi Pendidikan. Yogyakarta: Media Abadi

Yusuf, Umari dan Safrudin. 2014. Pengaruh Layanan Informasi Terhadap Perencanaan Pemilihan Karir Siswa Kelas IX Mts Darul Hikmah Pekanbaru. (Online) dalam https://jom.unri.ac.iddiakses pada tanggal 28 Maret 2019 